This is a self-archived version of an original article. This version may differ from the original in pagination and typographic details.

Author(s): Tergujeff, Elina; Kuronen, Mikko; Kautonen, Maria

Title: Kazoo training for $\mathrm{L} 2$ pronunciation practice and reduced foreign accentedness?

Year: 2020

Version: Accepted version (Final draft)

Copyright: @ 2020 Informa UK Limited

Rights: In Copyright

Rights url: http://rightsstatements.org/page/InC/1.0/?language=en

Please cite the original version:

Tergujeff, E., Kuronen, M., \& Kautonen, M. (2020). Kazoo training for L2 pronunciation practice and reduced foreign accentedness?. Innovation in Language Learning and Teaching, 14(3), 290302. https://doi.org/10.1080/17501229.2019.1586908 


\title{
Kazoo training for $L 2$ pronunciation practice and reduced foreign accentedness?
}

\author{
Elina Tergujeff*, Mikko Kuronen ${ }^{\mathrm{b}} \&$ Maria Kautonen $^{\mathrm{c}}$ \\ ${ }^{*}$ bc Department of Language and Communication Studies, University of Jyvaskyla, Jyväskylä, \\ Finland
}

Corresponding author:

*Elina Tergujeff

Department of Language and Communication Studies

P.O. Box 35

FIN-40014 University of Jyväskylä

elina.tergujeff@jyu.fi

$+358408053218$

ORCID iD: 0000-0002-3867-9915

$\mathrm{PhD}$ Elina Tergujeff is a Postdoctoral fellow in the Department of Language and Communication Studies, University of Jyväskylä. Her research interests include second language pronunciation teaching and learning, comprehensibility, intelligibility and accentedness. As for this study, Tergujeff's research activities were funded by the Society of Swedish Literature in Finland (SLS).

Co-authors:

${ }^{b}$ Mikko Kuronen

Department of Language and Communication Studies

P.O. Box 35

FIN-40014 University of Jyväskylä

mikko.j.kuronen@jyu.fi

+358408053242

ORCID iD: 0000-0001-5971-7063

$\mathrm{PhD}$, Senior lecturer Mikko Kuronen does research and teaches in the Department of Language and Communication Studies, University of Jyväskylä. His research interests include Swedish and Finnish phonetics and second language pronunciation learning. Kuronen is the principal investigator and head of a project concentrating on pronunciation teaching and learning with Swedish as L1 and L2 (www.jyu.fi/fokus). The project is funded by the Society of Swedish Literature in Finland (SLS).

${ }^{c}$ Maria Kautonen 
Department of Language and Communication Studies

P.O. Box 35

FIN-40014 University of Jyväskylä

maria.e.e.kautonen@jyu.fi

+358408053328

ORCID iD: 0000-0002-0688-7445

MA Maria Kautonen is a doctoral student in Swedish language in the Department of Language and Communication Studies, University of Jyväskylä. In her PhD study, she focuses on L2 pronunciation learning and assessment with Finland-Swedish as L2. Her research has been funded by the Society of Swedish Literature in Finland (SLS) 2015-2017. 


\title{
Kazoo training for $\mathrm{L} 2$ pronunciation practice and reduced foreign accentedness? \\ 1
}

\begin{abstract}
This paper presents a controlled pretest-training-posttest study on using a small membraphone instrument called kazoo for L2 pronunciation practice and reducing foreign accentedness. Learners were recorded for free speech before and after a six-week pronunciation and oral skills course including L2 prosody training with personal kazoos. A control group did not receive any kazoo training but did similar tasks in regular speech. Samples of all learners' free speech before and after the course were rated for foreign accentedness by L1 speakers. In addition, learners taking part in the kazoo group were interviewed in focus groups to ascertain their views on kazoo training. The results imply that the kazoo has potential as a pronunciation teaching and learning tool. Even if a group-specific analysis did not yield clear results, developing on an individual level was more common in the kazoo group. Moreover, many of the learners found positive aspects about kazooing. However, problems occurred as well; these are also reported on in this paper to hopefully help others who wish to conduct further teaching experiments and develop specialised tasks and materials for kazoo pronunciation practice.
\end{abstract}

Keywords: L2 pronunciation, foreign accent, teaching experiment, kazoo, learner interview

\section{Introduction}

Kazoo (see Picture 1) is a musical instrument, to which one hums in order to make a buzzing sound. Mere blowing into the kazoo does not create a sound. Using kazoos for second/foreign language pronunciation teaching and learning is probably not very common or even familiar to many language teachers. However, kazooing has been recommended for teaching speech prosody already in the 1970s (Gilbert 1978). The recommendation is based on the kazoo's buzzing sound blurring the individual speech sounds, hence drawing attention to what can be heard clearly: prosody. In addition, kazoos are cheap to buy and add to the variety of pronunciation teaching techniques. Even though pronunciation has gradually gained increased attention within the field of second language research, as stated by e.g. Derwing (2010) and Pennington (2015), practical studies on teaching techniques are still scarce and hence extremely welcome (Derwing and Munro 2015, 25). Thus, we decided to take up a classroom study to

\footnotetext{
${ }^{1}$ The research design is a result of collaboration between the authors. Author A was responsible for writing the article, and collecting and analysing the accentedness ratings, while author $\mathrm{B}$ was responsible for the teaching experiment. Author $\mathrm{C}$ conducted the learner interviews, and all authors took part in analysing them. In addition, authors $\mathrm{B}$ and $\mathrm{C}$ participated in editing the manuscript.
} 
investigate the potential of kazoo training for reducing foreign accentedness and as a pronunciation teaching and learning tool in general. This paper presents findings from a teaching experiment, in which L2 prosody was taught with the kazoo in a controlled pretesttraining-posttest setting. To study the effects of kazoo training, participants' productions of free speech before and after the teaching experiment were rated for foreign accentedness by native speakers. Also, the participants were interviewed to ascertain their experiences in training with the kazoo.

[Picture 1 around here.]

Kazoo's buzzing sound is produced with a vibrating membrane in the instrument. Hence, the kazoo is one type of a membraphone. The membraphone technique was also used in the eunuch flute (or onion flute, or mirliton) in the 16th and 17th century. However, membraphones are known already from Ancient Greece and traditional African societies, where they were used for impersonating voices of the dead in ceremonies. (Montagu 2007, 6.) In its current form, kazoo is known as an American invention from the 1850s, although documented proof of the origin of the instrument is not available. Kazoos may be mainly used as children's toys, but they had a significant role in blues and jazz in the 20th century. The kazoo is worth considering a serious instrument, as there are thousands of kazoo bands in the United States alone, and well-established composers and artists such as Leonard Bernstein and Ringo Starr have used kazoos in their music. (New York Times, February 6, 1993.)

Most research on kazooing has been done in the fields of music and music therapy. Anyone who can hum can play the kazoo without prior musical training or experience, and because of this democratic nature of the kazoo, they are commonly used in music therapy (see e.g. Wetherick 2014). Research suggests that as kazoos mask the voice, many inhibitions, such 
as the natural embarrassment of exposing one's voice out loud, can be removed (Bodner and Gilboa 2006). In another context, studying music and music theory has been found to benefit from kazooing. For example, young music theory students were assumed as being too intimidated for singing out loud, so kazoos were introduced in a teaching experiment by Snodgrass (2007). The students were motivated to practise on the kazoos, and their singing was strong. They developed in singing melodies by sight (i.e. prima vista, straight from the notes without hearing or practising the melody), and the teacher was able to correct those who were slightly off-pitch. Moreover, the student feedback included a comment on hiding behind the kazoo making a student feel more at ease with their own voice.

Benefits of the kazoo discovered in the fields of music therapy and music teaching could potentially help second and foreign language learners as well. Especially removing or decreasing the embarrassment of speaking out loud would be welcome as for learners with low willingness to communicate (WTC, McCroskey and Baer 1985, for L2: MacIntyre and Charos 1996; MacIntyre et al. 1998) and/or high language anxiety, in particular. As scholars have suggested, willingness to communicate should be considered an important learning goal (MacIntyre et al. 1998; Dörnyei 2003). Many learners do not feel at ease speaking a second/foreign language in front of a class (e.g. Kjellin 2002, 139-140). Therefore, methods enabling learners to practise their pronunciation without anxiety or embarrassment are needed, and kazoo training may be one option.

Gilbert (1978) bases her recommendation for using kazoos in language learning and teaching on that most productive teaching should appeal to both sides of the brain; whereas the left hemisphere is crucial for language, the right hemisphere is important for melody. Current knowledge on speech lateralization suggests that the issue is more complex (see e.g. Watkins and Devlin 2008; Peelle 2012). Nevertheless, Gilbert (1978) suggests that as pronunciation processes are spatial and melodic tasks, the verbal approach may be appealing 
to the wrong side of the brain. Thus, she feels musical aids should not be merely nice supplements but rather a fundamental teaching approach. Gilbert recommends kazoos for intonation and stress, but also sees the potential of using kazoos to demonstrate emotional patterns. She points out that learners may not hear intonation from normal speech very well, because they are struggling with strange sounds, word meaning, and difficult grammar all at once. The kazoo offers a speech model that is stripped of everything but intonation and stress. Gilbert (1978) names the kazoo "probably the best tool a pronunciation teacher could have" and is of the opinion that the kazoo gets faster results than e.g. visual cues (cf. Gilbert 1980 below). She also states that students having personal kazoos may increase the effects.

Gilbert (1980) has studied the effect of using personal kazoos on the perception of prosody. In a series of pilot studies, she tested if it was possible to identify a language based on prosody alone and how perceptive and production training affect the identification. A buzzlike resynthesis of free speech in Japanese, Cantonese and English was played to speakers of those languages. The listeners were to identify in a pre-test and a post-test which language was spoken. The listeners were divided into a passive group, active group, and a control group. Between pre-test and post-test, the passive group received perception training in the buzz-like resynthesis of the three languages, whereas the active group also imitated the stimuli using the kazoo. The control group received no training. After several adjustments to the research design concerning the time span of the pre-test-training-post-test setting, listeners' L1, the amount of training, and the length of training sessions, Gilbert was able to find significantly more improvement in the identification by those who had trained with the kazoo. This result was achieved by using L1 Japanese listeners who received four 15-minute training sessions within one week, which was the time between pre-test and post-test. Gilbert concludes that people can tell the difference between the given languages based on prosody alone, and that training especially active mimicry with the kazoo - can increase this ability. 
As Gilbert (1980) only studied the effects of kazoo training on receptive skills, we decided to investigate kazoo's potential for L2 speech production. In the present study, L2 Swedish was taught to L1 Finnish-speaking learners. Half of the participants aimed for the Sweden-Swedish variety, whereas the other half aimed for Finland-Swedish, which is a distinct variety spoken in Finland. The learners studied on a course where they could themselves choose their target variety. As kazoo training was used for the learning of prosody, we will now briefly present the most important prosodic challenges and learning goals for Finnish-speaking learners of Swedish. These are the realisation of stress, rhythmic pattern and tonal word accents (in Sweden-Swedish). The challenges are based on the differences between Finnish and Swedish prosody.

In Sweden-Swedish, duration is the main correlate of stress: stressed syllables are long, while unstressed syllables are more or less short, or at least shorter than stressed syllables (Kuronen and Tergujeff 2018; Bruce 2010, 85). In Finnish, the main correlates of stress are fundamental frequency and amplitude, while duration has a minor role as a stress correlate compared to Sweden-Swedish, partly because length is used extensively for phonological contrasts (see e.g. Ullakonoja et al. 2014). Thus, there is a greater prosodic - rhythmic or durational, to be exact - difference between the stressed and the unstressed part(s) of speech in Sweden-Swedish than in Finnish. The acquisition of this rhythmic feature in Sweden-Swedish seems to be of great importance for perceived foreign accentedness (Kuronen and Tergujeff 2017). In addition, Sweden-Swedish has two tonal word accents (see e.g. Riad 2014, 181-191), while Finnish has no lexical tones. As tonal word accents occur only in stressed syllables, this feature also adds to the prosodic difference between stressed and unstressed syllables in Sweden-Swedish. Previous research has discovered that aspects of Sweden-Swedish prosody are difficult but possible to learn for L1 speakers of Finnish (Kuronen and Tergujeff 2018; Kuronen, Ullakonoja and Kautonen 2016; Kuronen 2015). 
Finland-Swedish differs in some prosodic respects from Sweden-Swedish (see e.g. Helgason, Ringen and Suomi 2003). Finland-Swedish resembles Finnish regarding stress correlates: fundamental frequency and amplitude are the main correlates of stress, and duration plays a minor role (Vihanta, Leinonen and Pitkänen 1990). Still, the difference between stressed and unstressed syllables is greater in Finland-Swedish than in Finnish. Thus, even though learning Finland-Swedish can be considered less demanding for L1 Finnish-speaking learners (see e.g. Kautonen 2017), both varieties include prosodic learning goals, making them suitable target varieties for the present study.

\section{The Present Study}

\subsection{Aim and Research Questions}

The aim of this study is to investigate learners' experiences and the effect of kazoo training on reducing foreign accentedness. Thus, a teaching experiment was arranged with a pretesttraining-posttest setting, including an experimental group and a control group. The following research questions were set for the study:

1. How do learners experience the kazoo as a learning tool?

2. Can kazoo training help reduce the rate of foreign accent in L2?

Due to lack of previous research, it is difficult to predict the results. Gilbert's $(1978 ; 1980)$ work is encouraging, and previous studies (e.g. Kuronen and Tergujeff 2018) on L1 Finnishspeaking learners' development in Swedish prosody gives reason to believe that reducing foreign accentedness in these learners is possible. However, prosody is not the only aspect of pronunciation that influences the perception of foreign accent. Several studies (e.g. Boyd, 
Abelin and Dorriots 1999; Boyd and Bredänge 2013; Kuronen and Zetterholm 2017) point to individual sounds playing a role in foreign accentedness of Swedish, along with prosodic features. As training with the kazoo will obviously be of no help in developing the pronunciation of individual sounds, the possible effects of kazoo training will have to do with prosody alone.

\subsection{Participants}

The participants of the present study were advanced L1 Finnish-speaking adult learners of Swedish ( $\mathrm{n}=20)$ and L1 Swedish-speaking listeners $(\mathrm{n}=77)$. The learners had studied Swedish for at least six years before entering their current educational context, in which they pursue a university degree in Swedish language and/or second language teaching. Half of the learners $(n=10)$ aimed for the Sweden-Swedish variety, whereas the other half $(n=10)$ targeted FinlandSwedish. Similarly, the native-speaker listeners represented the Sweden-Swedish $(n=37)$ and Finland-Swedish $(\mathrm{n}=40)$ varieties. In addition, native speakers of Sweden-Swedish $(\mathrm{n}=2)$ and Finland-Swedish $(\mathrm{n}=2)$ were used as control speakers. All native speakers - listeners and control speakers - were recruited in educational contexts in Sweden and in Finland, and they were either experts or students in a language or related field (e.g. Swedish as a second language, language education, phonetics).

\subsection{Teaching Experiment}

The learners took part in an intensive oral skills course in Swedish, which combined explicit teaching of Swedish phonology and phonetics (including segmental and prosodic features of speech), conscious pronunciation training, and more general oral skills practice. The approach was interactional, including discussion on different aspects of oral language skills in Swedish. The major differences between the Sweden-Swedish and Finland-Swedish varieties as for 
pronunciation were covered during the course, and the learners got individualized feedback on their pronunciation according to their choice of target variety. The course took six weeks altogether, including two 90-minute sessions per week. Teaching took place in a language laboratory, which enabled recording learners' speech. Listening to one's own pronunciation was used as one of the teaching methods.

The participants $(n=20)$ were volunteers from three teaching groups of the course, following the same course plan as for the contents and the overall working methods. The sole difference was that the participants $(\mathrm{n}=10)$ in Group 1 trained with personal kazoos. The control group ( $\mathrm{n}=10)$ was formed of learners from two other groups (Group 2 and Group 3) to reach a balance between participants targeting Sweden-Swedish and Finland-Swedish. Groups 1 and 2 were taught by the same instructor, but Group 3 was taught by another instructor due to staff arrangements that were beyond our control. However, this slight difference is not considered crucial as for the learning results, because the contents and the overall teaching methods were identical in all groups.

As no explicit kazoo-playing materials or teaching tips are generally available, we decided to take on the recommendation to use kazoos, and applied them to the kind of materials and tasks we would have used in teaching also without the kazoo. Simply put, the kazoo training consisted of working on the same materials and tasks that the controls practised on without the kazoos. For example, stress patterns in short dialogues were discussed, marked to the text and read aloud. Kazoo training was restricted to sessions that dealt with prosody (mainly rhythm) and the kazoos were used for approximately 10 minutes per session. Altogether, the experimental group trained with the kazoos for approximately 60 minutes, which is equivalent to the amount of training the participants received in Gilbert (1980). We wish to emphasise that the instructor had no prior experience in actually using kazoos in teaching; however, he had familiarised himself with the recommendation in the literature and 
how to play the kazoo. In addition, ideas on how to use the kazoo in the teaching experiment were discussed among the authors of this paper. The idea of the experiment was to simulate a situation in which a teacher decides to try out a new method based on a recommendation but without special training or ready-made tasks or materials designed for the method.

\subsection{Data and Procedure}

The learners were recorded for free speech and read-aloud tasks (not dealt with in this study; see Kuronen and Tergujeff 2017; 2018) before and after the course. The free speech task consisted of picture story-telling (ca. 3 minutes), samples of which were used as material in a listening test conducted for the present study. The learners were asked to tell freely about two images, which both pictured a yard with children engaged in different activities, such as reading a book, playing ball, and riding a bicycle. The two images featured different children and different activities. The same images were used for both pretest and posttest, and identical materials were collected from four native speakers of Swedish to be used as control items in the listening test. Speech samples from all participants were chosen so that they represented the best 20 seconds of the speaker's free speech task before and after the course. This was done because many of the participants struggled with producing grammatically accurate free speech, and we did not wish ungrammatical structures to interfere with listeners' judgments. This may have been the case if the speech samples had featured the participants' first 20 seconds of the speaking task, which is a methodological choice commonly made in previous research (e.g. Munro and Derwing 1999; Saito, Trofimovich and Isaacs 2016). In determining the best 20 seconds, criteria included grammatical accuracy and overall fluency.

Speech samples were admitted to a listening test with 77 native speakers of Swedish. Learners who aspired for Sweden-Swedish pronunciation were rated by speakers of Central-Swedish from the Stockholm area, whereas those who pursued Finland-Swedish were 
rated by speakers of that variety. The listeners gave scalar evaluations of the strength of the speakers' foreign accent (accentedness ratings) and of their perception of how easy or difficult the speaker is to understand (comprehensibility ratings; for terminology, see e.g. Derwing and Munro 2015, 3-5). However, the comprehensibility ratings yielded such good scores already in the pretest that the learners could simply not make much progress in this respect. Hence, the comprehensibility ratings were disregarded in this study. The ratings were done on a 7-point scale $(1=$ no accent, $7=$ extremely strong accent $)$ with an online survey tool. All participants agreed with transmitting their 20 -second sound samples over the Internet.

In addition to the ratings, the experimental-group learners were interviewed in focus groups of 3-4 learners to explore their views on using the kazoo as a teaching/learning tool. The interviews were semi-structured and thematic, and they were conducted at the end of the teaching experiment. The interviews focused on pronunciation learning during the course and the teaching methods used. Specific questions about the kazoo were included, e.g. what the learners thought of its effects on learning, whether they practised on it at home, and whether they would use it themselves as teachers.

\subsection{Analyses}

Data obtained from the focus group interviews were robustly transcribed, and a qualitative thematic analysis was conducted on them in a researcher triangulation procedure. Researcher triangulation is a means of strengthening reliability of qualitative research. The idea is not to rely on a single researcher's interpretation but to co-construct the analysis together in an expert group (Denzin 1978, 303). The authors plus another expert specializing in questions of L2 Swedish pronunciation were involved in the triangulation. Each of the four experts first coded the transcripts for the following themes rising from the data: benefits, challenges, using kazoos in teaching, and the fun factor. Next, the themes were discussed by the experts, who then co- 
constructed the analysis. Quantitative data obtained from the accentedness ratings were admitted to statistical analyses to investigate the possible effect of training. Statistical significance of the difference between learners' pre- and posttest speech sample ratings were tested by using a paired-samples t-test. Effect sizes were calculated using Cohen's $d$, which indicates the difference between means in terms of standard deviation units (Cohen 1988). Effect sizes were interpreted following the general guidelines: small effect $>0.2$, medium effect $0.5-0.8$, large effect $0.8-1.3$, very large effect $>1.3$.

\section{Results}

\subsection{Learner Interviews}

Participants were divided on the usefulness of kazoo training: some found it truly helpful (Example 1), whereas some thought it did not benefit their pronunciation learning. However, many of the participants that were sceptical about the benefits of the kazoo for their own pronunciation learning recognised its potential for various aspects. They emphasised that they understood the idea and stated that it could have worked for someone else. Novelty of the method was seen as an asset (Example 2), and kazoos were welcomed to add variety to L2 teaching methods and learning activities. Intonation (Example 3), rhythm and stress were mentioned as factors that may benefit from kazoo training - in both perception and production. Thus, kazoos were seen to promote focus on prosody, even though it was mentioned that simply humming without the kazoo might have had the same effect.

Example 1. "Kyllä se niinku oikeesti on hyödyllinen, et sitä ois voinu melkein ehkä sit vähän enemmänki --““ 
"It was like truly useful, and we could have perhaps actually used it even more $-”$

Example 2. "Ihan hauska idea ja tavallaan kyl siinä vähän ehkä just ehkä se sen niinkun menetelmän uuden- tavallaan niinku uutuus toi siihen semmosta lisää, et sen tavallaan huomas että hei tääki on tapa huomata- niinkun oppia tota painoa tossa lauseessa. Mut sit mä en osaa sit sanoo sitte kuinka kovaa se tehos.”

"Pretty nice idea, and in a way, the method being new, the novelty added to it, and you noticed that hey, this is one way to notice like stress in the sentence. But I don't know how well it worked."

Example 3. “-- mä huomasin sen intonaation paljon paremmin [kazoolla] ku pelkästä puheesta."

"I noticed the intonation a lot better [with the kazoo] compared to regular speech.”

Many learners stated in the interviews that practising with the kazoo was fun. It sounded funny in a positive sense but also invoked some negative fooling around in class (Example 4). In connection with mere humming having the same effect as kazooing, it was stated that practising with the kazoo is more fun (Example 5) and is more concrete. Learners also joked about using their personal kazoos for May Day Carnival celebrations, which is a clear indication of kazoos appealing to their sense of humour. 
Example 4. "Se meni vähän itellä sellaseksi hassutteluksi että tuli puhalleltua sellasia kaikenlaisia muita ääniä ku niitä varsinaisia repliikkejä mitä piti puhallella."

"For me it slipped into fooling around a little bit. I whistled all kinds of sounds other than the lines we were supposed to."

Example 5. “-- Mä vaan sitten hymisin [ilman kazoota] sen saman homman. Se niinku mun mielestä ajoi saman asian mutta ei se nyt. Just onhan se sillä kazoolla on se nyt vähän hauskempaa kun se kuulostaa hassulta.”

"Then I just hummed the same thing [without the kazoo]. I thought it had the same effect but no, I mean it's more fun with the kazoo because it sounds funny."

As the learners taking part in the kazoo experiment were mainly future language teachers, they were asked whether they considered the method something they would use in their own teaching. Learners were generally open to the idea of using kazoos, but they had trouble thinking of suitable learner groups for kazooing. Some considered kazoos suited for motivating young learners (Example 6), but also for adults that were ready to hurl themselves into playful activities (Example 7). Some suspected lower and upper secondary school pupils reluctant to take part in kazooing, and pupils fooling around too much with the kazoos was a common concern. Further, large groups and groups with restless pupils were mentioned as contexts in which kazoos might be better avoided. One interviewee pointed out that the method is worth trying, if even a couple of learners find it beneficial. Kazoos were recommended for 
demonstrating stress; some found the method more suitable for introducing topics rather than for actual pronunciation practice.

Example 6. "Voi se ehkä motivoida jotain muksuja jotka ei muuten ehkä oo niin motivoituneita ruotsin opiskeluun jossain yläasteella tai jossain, tai sit se voi myös mennä aivan läskiks.”

"It might motivate some kids who are otherwise not so motivated to study Swedish, like in lower secondary school or so. Or it can turn into sheer fooling around.”

Example 7. “Ja sit täällä yliopistossa ehkä ainut, silleen alkaa olemaan sen verran avoin että okei no helvetti jos tää nyt pitäs toimia ni yritetää ees.”

"And here in the university, it might be the only place. One starts to be open, like okay, what the hell, if this should work, let's at least give it a try.”

When reflecting on the possible use of kazoo in their own teaching, the participants emphasised the importance of extensive instruction. This was probably due to themselves having severe challenges with getting started on the kazoo. Many of the participants indicated in the interviews that they found it difficult at first to produce the buzzing sound. It was mentioned, for example, that producing the sound required speaking somewhat louder than they were used to speaking, which was straining and distracted their focus (Example 8). Other challenges had to do with the amount of practice: kazoos were used too little in class (Example 9), and some participants were poorly motivated to kazoo in their free time. Participants also seemed to be 
afraid of or suffering from negative attitudes against the kazoo in their surroundings: one was worried about what their neighbours would think if they heard the kazoo through the walls, and another stated that their girlfriend did not like them kazooing at home. In addition, some participants found it challenging to take kazooing seriously.

Example 8. "Se keskittyminen meni mulla ehkä siihen että mä saan sieltä pillistä jonkun äänen eikä siihen että miten mä teen ne äänenpainot. Mä ymmärrän sen että siitä olis siihen hyötyä ja sit ku mä vähän opin käyttään sitä ni se meni paremmin."

"My concentration was on getting a sound out of it and not on how to produce the stress. I understand that it would be beneficial for stress, and when I learnt to use it a little, it worked better.”

Example 9. “-- siis periaatteessa oikeesti kyllä ymmärsin sen idean mikä siinä ois et se varmasti niinku auttanu, et loppupeleissä me ei kyl hirveesti taidettu käyttää sitä.”

"In principle, I did understand the idea of it and I'm sure it would have helped, but in the end, I don't think we used it that much."

\subsection{Accentedness Ratings}

Overall, accentedness ratings did not reveal much difference between pretest and posttest speech samples. There was only a small but statistically significant difference between pretest and posttest mean scores for both the kazoo group and the control group. On average, the kazoo 
group was rated slightly less accented in posttest than in pretest, whereas the controls were rated slightly more accented (see Table 1). The difference between pretest and posttest was statistically significant for both groups, but effect sizes proved minimal. This means that the differences between pretest and posttest cannot be explained by chance, but the actual effect of the differences is only minute. Hence, we cannot draw conclusions based on the group comparisons despite the opposite directions of development, but will next zoom in to explore the ratings on the level of individual learners.

[Table 1 around here.]

Learner-specific accentedness ratings demonstrated that not everyone presented a change in their accentedness as a result of the six-week intensive course, which is clearly reflected in the group-specific results presented above. In fact, only 11 out of 20 learners reached a statistically significant difference between pretest and posttest scores. Detailed results describing the development of these 11 learners are presented in Table 2. The rest of the learners cannot be taken into account, as there was (practically) no difference between pretest and posttest mean scores, and the minor differences may be explained by chance; however, see Appendix for all results. As for the learners who went over a statistically significant development, only 5 learners were able to reduce their rate of foreign accent. The 6 remaining learners developed in the opposite direction. Effect sizes varied from small to large; in most cases, the effect size was medium or large.

[Table 2 around here.] 
Reduced rate of foreign accentedness was found mainly among kazooers: 4 out of 5 learners reducing their accentedness were kazooers, meaning that only one control made this development. Out of the 6 learners that made a change in the opposite direction, 2 were kazooers and 4 were controls. Thus, it appears that kazooers succeeded better in reducing their foreign accent. In addition, reducing foreign accent seems to have worked slightly better with learners who targeted Finland-Swedish: 3 out of 4 kazooers targeting Finland-Swedish received lower mean scores for accentedness in the posttest, whereas all 3 controls targeting FinlandSwedish were judged to have a higher rate of accentedness. This was confirmed by a pairedsamples t-test: those aiming for Sweden-Swedish did not present a statistically significant difference between their pretest and posttest mean scores, whereas those aiming for FinlandSwedish did (see Table 3). Moreover, learners of Finland-Swedish made the change for the positive. The effect size was small. These results were obtained using all data; not only learners who made a statistically significant change from pretest to posttest.

[Table 3 around here.]

\section{Discussion}

Group-specific analyses, i.e. kazooers vs. controls, did not indicate that kazoo-playing would clearly lower the rate of foreign accentedness. Overall, many of the learners did not demonstrate a statistically significant difference between their pretest and posttest scores, but their foreign accentedness was judged more or less the same both before and after the intervention. These results highlight the difference between our experiment and Gilbert's (1980) study: Gilbert's aim to reach receptive effects with 60 minutes of kazoo training was successful, whereas our investigation on reducing foreign accentedness in free speech with the same amount of kazooing did not yield such clear results. To apply the learnt skills into free 
speech would possibly have needed more practice; learners themselves stated in the interview that the kazoo was used only little (Examples 1 and 9). In a previous study (Kuronen and Tergujeff 2018), the same learners were able to make substantial prosodic developments during this teaching experiment, when assessed from read-aloud speech. This clearly indicates the difficulty of applying skills to free speech. Also, not all development may always appear directly after an intervention. On the contrary, learners may be less confident (Lintunen and Mäkilähde 2015) and feel puzzled by all new information and find it hard to concentrate on several things simultaneously, which was even mentioned in the interviews. Applying learnt features into free speech may take time. Hence, the lack of delayed posttest is an obvious limitation of the present study.

Target variety specific analyses revealed that learners of Sweden-Swedish hardly demonstrated any change in their rate of foreign accentedness, whereas learners of FinlandSwedish did: kazoo group targeting Finland-Swedish reduced their foreign accentedness, but the control group developed for the negative. Finland-Swedish was assumed an easier target variety to begin with, because it has less prosodic learning goals compared to Sweden-Swedish. Learners could hence focus on rhythm and disregard tonal aspects, which means they have been under lighter cognitive strain during the learning process (cf. Ullakonoja 2011). The results imply that kazoo training works better if the prosodic learning goals are limited to rhythm - or perhaps any one aspect - whereas focusing on two aspects (in this case: rhythm and tonal features) simultaneously may be too challenging.

When analysed on the level of individual learners, reducing foreign accentedness was clearly more common among learners in the kazoo group. Thus, we see potential in the kazoo as a pronunciation teaching and learning tool - especially if used extensively and with tasks and materials explicitly designed for the kazoo. We wish to reiterate that our teaching experiment was conducted without much previous experience in practising on the kazoo, and 
that kazooing was applied to normal pronunciation tasks that otherwise were done in regular speech. Still, almost all learners who reduced their foreign accentedness were in the kazoo group. It is also noteworthy that segments as well play a role in perceived accentedness (e.g. Boyd, Abelin and Dorriots 1999; Boyd and Bredänge 2013; Kuronen and Zetterholm 2017), and as many learners practising on the kazoo succeeded in reducing their accentedness, kazooing cannot be seen to negatively affect the development of segments. The possibility of the kazoo hindering or disturbing the development of segments occurred to us in planning the experiment but fortunately proved an unnecessary concern. However, if kazoo training is practised extensively, teachers should make sure that sufficient attention is paid to individual sounds as well.

Interviews with the learners also support kazoo's potential as a pronunciation teaching and learning tool. Even though some of the learners did not feel they personally benefitted from kazooing, they were positive about the idea; some found it more suitable to other learner groups, and some found it valuable in terms of its novelty effect and in adding to the range of classroom activities. In our view, new ideas and techniques are welcome to language instruction, as varied activities are crucial for motivation and maintaining interest. In addition, the interviews clearly demonstrated that training on the kazoo was viewed as fun, which also increases motivation. The fact that kazoos mask the user's voice has been found to remove inhibitions such as embarrassment of speaking or singing in front of others (Bodner and Gilboa 2006; Snodgrass 2007). However, this issue was not raised by any of the interviewed learners. Hence, this study does not offer support to kazoos affecting language anxiety or willingness to communicate (WTC). Still, we want to point out that this aspect was not explicitly addressed by the interviewer, and we do not know whether any of the learners suffered from language anxiety or low WTC. Thus, the possibilities of kazoo training contributing to this matter calls for further investigation. 
Overall, more classroom research is needed on pronunciation teaching techniques, and we hope that our study will inspire teachers and researchers to conduct teaching experiments. As for future research regarding the kazoo, we would like to see kazoo teaching experiments conducted on children, who might form a better target group for kazooing despite the interviewees' concern for children losing focus and fooling around; children's natural enthusiasm for playful activities might deepen their engagement, and their lower level of target language proficiency might provide more opportunities for development. For example, participants with lower proficiency could be tested for comprehensibility, which is more important for communication in comparison to accentedness, and which is heavily influenced by prosody. In the present study, the participants were too advanced for this research purpose; hence, it was quite impossible for them to develop their comprehensibility, as they were very easy to understand already before the intervention. Future research should also focus on other languages, as this study only investigated the learning of Swedish by L1 Finnish speakers. The benefits of kazooing might come forth clearer in research designs with two languages diverging more radically from each other in regards to rhythm, e.g. L1 Spanish speakers learning Swedish or e.g. English.

\section{Conclusion}

The aim of this study was to shed light on using the kazoo as a learning and teaching tool for second language pronunciation and its possibilities for reducing foreign accentedness in second language (free) speech. The research entailed a practical teaching experiment with a controlled pretest-training-posttest setting, followed by listener ratings for foreign accentedness and learner interviews in focus groups. Participants were divided in their views on the usefulness of kazooing as for their own pronunciation learning, but they saw potential in it and could use it themselves in teaching with a suitable learner group. Kazooing was seen as a fun activity, 
adding variety to teaching techniques. Nevertheless, no indication of change as for willingness to communicate or embarrassment to speak out loud came up in the interviews. Accentedness ratings suggest that kazoo training has the potential of reducing foreign accentedness, especially in target languages with a limited amount of prosodic learning goals. At least in this study, kazooing mainly helped the learners of Finland-Swedish, whose prosodic learning goals were restricted to aspects of rhythm, whereas reducing accentedness was rare among learners of Sweden-Swedish, trying to tackle learning goals both rhythmic and tonal. In addition, this study gives no reason to suspect that small-scale kazooing would hinder the development of segmental features of pronunciation.

Based on the results of this study, we recommend that second and foreign language teachers familiarise themselves with kazooing for prosodic training and try it out with suitable learner groups. Kazoos are cheap to buy and add to the variety of classroom activities. Moreover, their novelty effect and fun factor may increase motivation among learners. What our experiment taught us is not to overestimate the ease of playing the kazoo. Even adults can have difficulties in learning how to make a sound. Hence, learners would benefit from careful instruction on how to get started on the kazoo, and tasks designed for how to control the sound. In addition, teachers should test different kazoo types and choose the kind for their learners that plays with relatively weak volume and air stream. Based on our experience, the cheap plastic kazoos are the easiest to play.

\section{Acknowledgements}

We would like thank all our participants and our kind colleague Henna Heinonen, who took part in the researcher triangulation procedure. In addition, we are grateful to Elisabeth Zetterholm for their help in data collection (control speakers) and to Veera Tergujeff for Picture 1 .

\section{Funding information}


This study is part of research project Fokus på uttalsinlärningen med svenska som mål- och källspråk (FOKUS, see www.jyu.fi/fokus), which is funded by the Society of Swedish Literature in Finland (SLS) 2015-2019. The foundation also supported Author A's work with an additional grant.

\section{No conflicts of interest}

\section{References}

Bodner, E., and A. Gilboa. 2006. "Emotional Communicability in Music Therapy: Different Instruments for Different Emotions?" Nordic Journal of Music Therapy 15 (1): 3-16. doi: 10.1080/08098130609478147

Boyd, S., Å. Abelin, and B. Dorriots. 1999. "Attitudes to Foreign Accents.” In Gothenburg Papers in Theoretical Linguistics 81, Proceedings from the Twelfth Swedish Phonetics Conference, edited by R. Andersson, Å. Abelin, J. Allwood, and P. Lindblad, 31-35. Gothenburg: University of Gothenburg.

Boyd, S., and G. Bredänge. 2013. "Utländska lärare i Sverige - attityder till brytning." In Svenska som andraspråk - i forskning, undervisning och samhälle, edited by $\mathrm{K}$. Hyltenstam, and I. Lindberg, 437-459. Lund: Studentlitteratur.

Bruce, G. 2010. Vår fonetiska geografi. Om svenskans accenter, melodi och uttal. Lund: Studentlitteratur.

Cohen, J. 1988. Statistical Power Analysis for the Behavioural Sciences. Hillsdale, NJ: Lawrence Erlbaum.

Denzin, N.K. 1978. The research act: A theoretical introduction to sociological methods. Second edition. New York: McGraw-Hill.

Derwing, T. M. 2010. "Utopian Goals for Pronunciation Teaching." In Proceedings of the 1st Pronunciation in Second Language Learning and Teaching Conference, Iowa State University, Sept. 2009, edited by J. Levis, and K. LeVelle, 24-37. Ames, IA: Iowa State University.

Derwing, T.M., and M.J. Munro. 2015. Pronunciation Fundamentals: Evidence-Based Perspectives for L2 Teaching and Research. Amsterdam/Philadelphia: John Benjamins Publishing Company.

Dörnyei, Z. 2003. “Attitudes, Orientations, and Motivations in Language Learning: Advances in Theory, Research, and Applications." Language Learning 53 (1): 3-32. doi: $10.1111 / 1467-9922.53222$

Gilbert, J. 1978. GADGETS: Some Non-Verbal Tools for Teaching Pronunciation. TESL Reporter, Winter 1978.

Gilbert, J. 1980. "Prosodic Development: Some Pilot Studies." In Research in Second Language Acquisition: Selected Papers of the Los Angeles Second Language Acquisition Research Forum, edited by R.C. Scarcella, and S.D. Krashen, 110-117. Rowley, Mass.: Newbury House.

Helgason, P., C. Ringen, and K. Suomi. 2013. "Swedish Quantity: Central Standard Swedish and Fenno-Swedish." Journal of Phonetics 41 (6): 534-545. doi: 10.1016/j.wocn.2013.09.005 
Kautonen, M. 2017. "Finskspråkiga talares intonation av finlandssvenska i påståendeyttranden i fritt tal." Folkmålsstudier 55: 31-60.

Kjellin, O. 2002. Uttalet, språket och hjärnan - teori och metodik för språkundervisningen. Uppsala: Hallgren \& Fallgren.

Kuronen, M. 2015. "Tonaccenterna i avancerade finska inlärares svenska - en akustisk studie." Nordand 1-2015: 53-80.

Kuronen, M., R. Ullakonoja, and M. Kautonen. 2016. "Inlärningen av de svenska tonaccenterna hos finska S2-talare - automatiseras uttalet?" Språk och Stil 26: 161-194.

Kuronen, M. and E. Tergujeff. 2018. "Second language prosody and its development: Connections between different aspects." The Language Learning Journal. Ahead-ofprint online. doi: 10.1080/09571736.2018.1434228

Kuronen, M. and E. Tergujeff. 2017. "L1 listeners' perception of L2 pronunciation - Effect of prosody on accentedness ratings in Swedish." In Näkökulmia toisen kielen puheeseen - Insights into Second Language Speech, edited by M. Kuronen, P. Lintunen and T. Nieminen. AFinLAe: Soveltavan kielitieteen tutkimuksia 10. 214-233.

Kuronen, M. and E. Zetterholm. 2017. "Olika fonetiska drags relativa betydelse för upplevd inföddlikhet i svenska." Nordand 2-2017: 134-156. doi: 10.18261/issn.2535-33812017-02-03

Lintunen, P., and A. Mäkilähde. 2015. "More Training Needed, but Will It Make Me Less Confident? A Learner Perspective on English Pronunciation.” In EPIP4 Proceedings, edited by J. Volín, 91-94. Prague: Charles University in Prague.

MacIntyre, P. D., and C. Charos. 1996. "Personality, Attitudes, and Affect as Predictors of Second Language Communication." Journal of Language and Social Psychology 15 (1): $3-26$.

MacIntyre, P., R. Clément, Z. Dörnyei, and K. Noels. 1998. "Conceptualizing Willingness to Communicate in a L2: A Situational Model of L2 Confidence and Affiliation." The Modern Language Journal 82 (2): 545-62. doi: 10.1111/j.1540-4781.1998.tb05543.x

McCroskey, J.C., and J.E. Baer. 1985. "Willingness to Communicate: The Construct and Its Measurement." Paper presented at the annual convention of the Speech Communication Association, Denver, Colorado, November 1985.

Montagu, J. 2007. Origins and Development of Musical Instruments. Lanham, MD: Scarecrow Press.

Munro, M.J., and T.M. Derwing. 1999. "Foreign Accent, Comprehensibility, and Intelligibility in the Speech of Second Language Learners." Language Learning, 49 (1): 285-310. doi: 10.1111/0023-8333.49.s1.8

Peelle, J.E. 2012. "The Hemispheric Lateralization of Speech Processing Depends on What "Speech" Is: a Hierarchical Perspective." Frontiers in Human Neuroscience 6, 309. doi: 10.3389/fnhum.2012.00309

Pennington, M.C. 2015. "Research, Theory and Practice in L2 Phonology: A Review and Directions for the Future." In Investigating English Pronunciation: Trends and Directions, edited by J.A. Mompean, and J. Fouz-González, 149-173. Houndmills, UK: Palgrave Macmillan.

Riad, T. 2014. The Phonology of Swedish. Oxford: Oxford University Press. 
Saito, K., P. Trofimovich, and T. Isaacs. 2016. "Second Language Speech Production: Investigating Linguistic Correlates of Comprehensibility and Accentedness for Learners at Different Ability Levels." Applied Psycholinguistics 37 (2): 217-240. doi: $10.1017 / \mathrm{S} 0142716414000502$

Snodgrass, J. 2007. The 8:00 a.m. Kazoo Experience. Music Educators Journal 94 (1): 14.

Ullakonoja, R. 2011. Da. Eto vopros! Prosodic Development of Finnish Students' Read-Aloud Russian during Study in Russia. Jyväskylä Studies in Humanities 151. Jyväskylä: University of Jyväskylä.

Ullakonoja, R., M. Kuronen, P. Hurme and H. Dufva 2014. "Segment duration in Finnish as imitated by Russians." In Social and Linguistic Speech Prosody. Proceedings of the $7^{\text {th }}$ international conference on Speech Prosody, edited by N. Campbell, D. Gibbon and D. Hirst. Available: http://fastnet.netsoc.ie/sp7/sp7book.pdf

Vihanta, V.V., K. Leinonen, and A.J. Pitkänen. 1990. "On Rhythmic Features in FinlandSwedish and Sweden-Swedish." In Nordic Prosody V: Papers from a Symposium, edited by K. Wiik, and I. Raimo, 325-350. Turku: University of Turku.

Watkins, K.E. and J.T. Devlin. 2008. "Transcranial Magnetic Stimulation (TMS) as a Tool for Studying Languages." In Handbook of the Neuroscience of Language, edited by B. Stemmer and H. Whitaker, 115-124. London: Elsevier.

Wetherick, D. 2014. "Music Therapy and Children with Language Impairment: Some Examples of Musical Communication in Action." Psychology of Music 42 (6), 864-868. doi: $10.1177 / 0305735614547716$ 


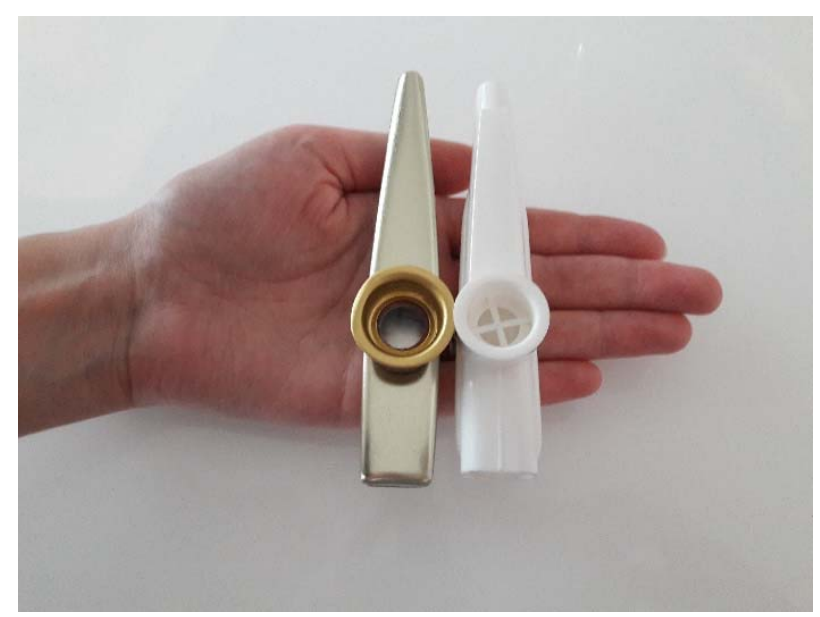

Picture 1. Kazoo in metal and in plastic.

\begin{tabular}{|l|l|l|l|l|l|}
\hline & pretest mean & posttest mean & change & t-test $p$ & Cohen's $d$ \\
\hline Kazoos & 3.59 & 3.43 & -0.16 & $.005^{* *}$ & .15 \\
\hline Controls & 3.47 & 3.62 & +0.15 & $.005^{* *}$ & .15 \\
\hline
\end{tabular}

Table 1. Group-specific pre- and posttest mean scores for foreign accentedness as judged by native-speaker listeners on a 7 -point scale ( $1=$ no accent, $7=$ extremely strong accent).

\begin{tabular}{|l|l|l|l|l|l|l|}
\hline speaker & $\begin{array}{l}\text { target } \\
\text { variety }\end{array}$ & pretest mean & posttest mean & difference & t-test $p$ & $\begin{array}{l}\text { Cohen's } \\
d\end{array}$ \\
\hline Kazoo 1 & Swe-Swe & 3.54 & 3.19 & -0.35 & $.035^{*}$ & .36 \\
\hline Kazoo 3 & Swe-Swe & 4.32 & 4.97 & +0.65 & $.001^{* *}$ & .57 \\
\hline Kazoo 5 & Fin-Swe & 4.90 & 4.35 & -0.55 & $.000^{* * *}$ & .67 \\
\hline Kazoo 8 & Fin-Swe & 3.55 & 2.70 & -0.85 & $.000^{* * *}$ & .87 \\
\hline Kazoo 9 & Fin-Swe & 2.28 & 1.73 & -0.55 & $.006^{* *}$ & .46 \\
\hline Kazoo 10 & Fin-Swe & 2.59 & 3.10 & +0.51 & $.002^{* *}$ & .53 \\
\hline Control 1 & Swe-Swe & 4.03 & 3.65 & -0.38 & $.004^{* *}$ & .50 \\
\hline Control 4 & Swe-Swe & 2.94 & 3.41 & +0.47 & $.039^{*}$ & .36 \\
\hline Control 7 & Fin-Swe & 4.26 & 4.75 & +0.49 & $.013^{*}$ & .42 \\
\hline Control 9 & Fin-Swe & 3.23 & 3.60 & +0.37 & $.034^{*}$ & .35 \\
\hline Control 10 & Fin-Swe & 2.85 & 3.33 & +0.48 & $.003^{* *}$ & .51 \\
\hline
\end{tabular}

Table 2. Learner-specific pre- and posttest mean scores for foreign accentedness as judged by native-speaker listeners on a 7 -point scale ( $1=$ no accent, $7=$ =xtremely strong accent $)$.

\begin{tabular}{|l|l|l|l|l|l|}
\hline group & pretest mean & posttest mean & difference & t-test $p$ & Cohen's $d$ \\
\hline Kazoo Swe-Swe & 3.65 & 3.73 & +0.08 & .309 & - \\
\hline Kazoo Fin-Swe & 3.57 & 3.24 & -0.33 & $.000^{* * *}$ & .29 \\
\hline Control Swe-Swe & 3.55 & 3.61 & +0.06 & .467 & - \\
\hline Control Fin-Swe & 3.39 & 3.60 & +0.21 & $.005^{* *}$ & .20 \\
\hline
\end{tabular}

Table 3. Target variety specific pre- and posttest mean scores for foreign accentedness as judged by nativespeaker listeners on a 7 -point scale ( $1=$ no accent, $7=$ extremely strong accent). 
Appendix: Learner-specific pre- and posttest mean scores for foreign accentedness as judged by native-speaker listeners on a 7-point scale ( $1=$ no accent, $7=$ extremely strong accent).

\begin{tabular}{|l|l|l|l|l|l|l|}
\hline speaker & $\begin{array}{l}\text { target } \\
\text { variety }\end{array}$ & $\begin{array}{l}\text { pretest } \\
\text { mean }\end{array}$ & $\begin{array}{l}\text { posttest } \\
\text { mean }\end{array}$ & difference & t-test $p$ & $\begin{array}{l}\text { Cohen's } \\
d\end{array}$ \\
\hline Kazoo 1 & Swe-Swe & 3.54 & 3.19 & -0.35 & $.035^{*}$ & .36 \\
\hline Kazoo 2 & Swe-Swe & 2.46 & 2.54 & +0.08 & .571 & - \\
\hline Kazoo 3 & Swe-Swe & 4.32 & 4.97 & +0.65 & $.001^{* *}$ & .57 \\
\hline Kazoo 4 & Swe-Swe & 4.19 & 4.22 & +0.03 & .872 & - \\
\hline Kazoo 5 & Fin-Swe & 4.90 & 4.35 & -0.55 & $.000^{* * *}$ & .67 \\
\hline Kazoo 6 & Fin-Swe & 3.83 & 3.36 & -0.47 & .316 & - \\
\hline Kazoo 7 & Fin-Swe & 4.33 & 4.03 & -0.30 & .124 & - \\
\hline Kazoo 8 & Fin-Swe & 3.55 & 2.70 & -0.85 & $.000^{* * *}$ & .87 \\
\hline Kazoo 9 & Fin-Swe & 2.28 & 1.73 & -0.55 & $.006^{* *}$ & .46 \\
\hline Kazoo 10 & Fin-Swe & 2.59 & 3.10 & +0.51 & $.002^{* *}$ & .53 \\
\hline Control 1 & Swe-Swe & 4.03 & 3.65 & -0.38 & $.004^{* *}$ & .50 \\
\hline Control 2 & Swe-Swe & 3.54 & 3.49 & -0.05 & .757 & - \\
\hline Control 3 & Swe-Swe & 3.22 & 3.11 & -0.11 & .440 & - \\
\hline Control 4 & Swe-Swe & 2.94 & 3.41 & +0.47 & $.039^{*}$ & .36 \\
\hline Control 5 & Swe-Swe & 4.03 & 4.41 & +0.38 & .085 & - \\
\hline Control 6 & Fin-Swe & 2.63 & 2.53 & -0.10 & .553 & - \\
\hline Control 7 & Fin-Swe & 4.26 & 4.75 & +0.49 & $.013^{*}$ & .42 \\
\hline Control 8 & Fin-Swe & 4.00 & 3.83 & -0.17 & .163 & - \\
\hline Control 9 & Fin-Swe & 3.23 & 3.60 & +0.37 & $.034^{*}$ & .35 \\
\hline Control 10 & Fin-Swe & 2.85 & 3.33 & +0.48 & $.003^{* *}$ & .51 \\
\hline
\end{tabular}

